\title{
Cardless banking in the Nelson Mandela Metropole: A means of financial inclusion for the excluded
}

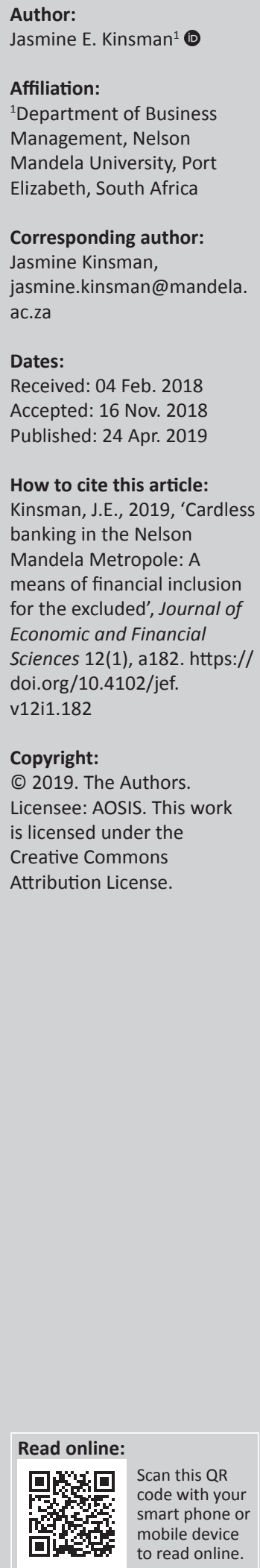

Orientation: The growth of mobile phone usage and wireless connection has transformed the manner in which financial services are provided. However, it has failed to increase the accessibility to formal banking facilities for the underbanked population.

Research purpose: To determine their perceptions and intentions of cardless banking among underbanked consumers.

Motivation for the study: The financial inclusion of underbanked consumers is increasingly important given the current social welfare payment crisis in South Africa.

Research design, approach and method: The study made use of a quantitative research approach using surveys to collect data from 175 underbanked consumers.

Main findings: The study revealed that underbanked consumers have positive perceptions of the complexity, trialability and compatible advantages of using cardless banking.

Practical/managerial implications: Underbanked consumers and social grant beneficiaries should be allowed to try cardless banking before using it to experience its benefits in order to assess how suitable it is to their circumstances without the risk of loss or barriers should they not prefer it. Little to no special training should be required in order to use cardless banking, and it must be easy to explain to their friends and family how it works.

Contribution/value-add: Recommendations are made to financial institutions who intend on capturing the underbanked consumer segment, the National Treasury and other governmental institutions who wish to increase financial inclusion to underbanked consumers and especially to South African Social Security Agency (SASSA) when considering an alternative payment method for social grant beneficiaries.

Keywords: cardless banking; underbanked consumers; financial services; social grant; SASSA.

\section{Introduction}

The large majority of South African consumers (93.8\%) have mobile phones (Community Survey 2016:91), while only $28 \%$ of the population make use of formal banking facilities (Global Findex 2014). This growth of mobile phone usage and wireless connection could transform the way financial services are provided, possibly increasing access to formal banking facilities to the underbanked population (Prior \& Santomá 2010:1). South Africa has attempted to decrease and accommodate the unbanked and underbanked population through the Mzansi account intervention following the financial services charter policy recommendations. There were approximately 6 million bank accounts opened over a period of 4 years. However, two-fifths of the accounts were inactive (Kostov, Arun \& Annim 2014). According to Istrate (2014:12), more banks have begun implementing different methods of cash withdrawal by considering changes to ATM machines or using of other types of terminals to dispense money.

Financial inclusion refers to enhancing individuals' financial capabilities and providing them with access to the formal banking sector (Figart 2013). Financial inclusion becomes a problem where the benefits outweigh the costs of participating but the access is limited because of external factors such as unaffordable fees, unsuitable products or long distances to travel (Demirgüç-Kunt \& Klapper 2012:1). In a study conducted by Gross et al. (2012) it was found that underbanked consumers are more likely to be younger, black and unemployed, and according to Global Findex (2014) only 28\% of low-income South African consumers older than 15 make use of formal banking facilities. The most recent statistics provided by Global Findex (2017) indicate that $66 \%$ of lowincome earners now have access to formal bank accounts, yet $28 \%$ indicated that they did not use them because the financial institutions were too far away, $38 \%$ indicated that it was too expensive, 
$22 \%$ lacked the necessary documentation and 27\% indicated that they did not have a formal bank account because they did not trust financial institutions. The most frequent mobile banking activity conducted by the respondents was account balance checks (Kostov et al. 2014:118-141), although unlike other financial transactions balance checking is a static function being that money does not flow into, out of or between accounts (Reeves \& Sabharwal 2013).

The financial inclusion of this population group is increasingly important given the current social welfare payment crisis in South Africa, where unauthorised and illegal deductions are made from the beneficiaries' social grants. As a result, the constitutional court has ruled that the contract with the foreign service provider that administers the payment of social grants was invalid in 2014 and instructed the South African Social Security Agency (SASSA) to find alternative methods of payment and restart the tendering process (Dasnois \& Maregele 2017). The SASSA is responsible for administering social grants to South African beneficiaries who qualify based on certain criteria. These grants include grants for older persons, disability grants, care dependency grants, foster child grants, child support grants, grants-in-aid and social relief of distress. The beneficiaries gain access to their grant payments through a SASSA card, or it may be deposited into their bank account (SASSA 2017). The term of the invalid contract with the service provider was set to come to an end as of 31 March 2017, but SASSA failed to make provisions for alternative methods of payment as instructed by the constitutional court; thus the social grant crisis in South Africa ensued, where more than 17 million beneficiaries were left with uncertainty as to whether they would receive their grants. Consequently, the constitutional court granted a 12-month extension with the current service provider to manage the crisis while SASSA sought an alternative service provider, which among others includes the South African Post Office (SAPO) (Dasnois \& Maregele 2017). A service agreement was thus signed between SASSA and SAPO in December 2017 where SAPO will commence with the payment of social grants from 01 April 2018 (Maphanga 2018).

It is thus clear that the South African financial services industry needs to be scrutinised to determine whether financial institutions that offer banking facilities have the technological capabilities to provide services to underbanked consumers. To bridge the gap between the underbanked and banked populations and realise the goal of financial inclusion of every individual, financial services could be incorporated with technology readily available to the underbanked community. It is thus important that a better understanding of the perceptions of the underbanked with regard to cardless banking solutions be investigated, in particular their financial education background, opinions on financial needs, aspirations and attitudes.

\section{Problem statement}

Gross et al. (2012) deduced that the primary reasons underbanked consumers had for not using mobile banking were that their banking requirements were currently being met with the existing services. Some gave the excuse of security concerns. Another reason Gross et al. (2012) found for individuals not adopting mobile banking was because they lacked bank accounts. Moreover, the respondents in the study stated that it was easier for them to perform tasks like payments with cash.

Despite underbanked consumers having a mobile phone and despite the facilities that are being made available to them, they are still not incorporating them in their money management systems. Furthermore, given the recent SASSA social grant crisis where an alternative service provider needs to be sought, it is important to first determine the perceptions these consumers have of the possible facilities that could be considered.

\section{Research hypotheses}

The perceptions of underbanked consumers towards cardless banking were investigated by considering the compatibility, complexity, trialability, observability and relative advantage of cardless banking and whether these perceptions influence underbanked consumers' intentions to use it. The following hypotheses were formulated to illustrate this relationship:

$\mathbf{H}_{1}$ : There is a positive relationship between underbanked consumers' perceived relative advantage of cardless banking and their intentions to adopt cardless banking.

$\mathbf{H}_{2}$ : There is a positive relationship between underbanked consumers' perceived compatibility of cardless banking and their intentions to adopt cardless banking.

$\mathbf{H}_{3}$ : There is a positive relationship between underbanked consumers' perceived trialability of cardless banking and their intentions to adopt cardless banking.

$\mathbf{H}_{4}$ : There is a positive relationship between underbanked consumers' perceived observability of cardless banking and their intentions to adopt cardless banking.

$\mathbf{H}_{5}$ : There is a positive relationship between underbanked consumers' perceived complexity of cardless banking and their intentions to adopt cardless banking.

These relationships are illustrated in Figure 1.

\section{Literature review}

The following section provides a brief overview of the nature of underbanked consumers and the cardless banking facilities

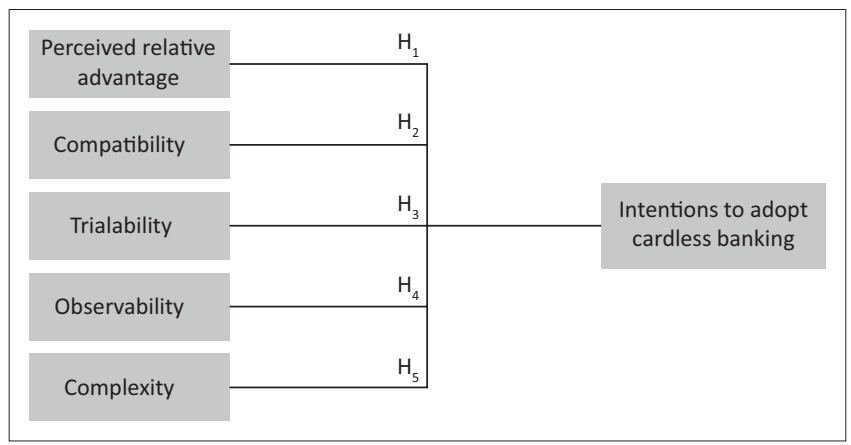

FIGURE 1: Factors influencing the underbanked consumer's perception of cardless banking. 
offered by both financial and non-banking institutions. In addition, possible factors that may influence underbanked consumers' perceptions of cardless banking are described.

\section{Underbanked consumers}

More than 2 billion people in developing countries still lack access to basic formal financial services, such as savings or checking accounts (The World Bank 2017). These consumers are referred to as 'underbanked consumers' and are predominantly poor people living in rural areas and cashbased economies (Bångens \& Söderberg 2008). Underbanked consumers often work informally and casually, lack upward mobility in their jobs and are financially insecure and uncertain about their future. They are unable to obtain loans from formal banking institutions, nor do they maintain savings formally because of the high costs involved and lack of a credit record, as the cost of borrowing informally is too high (Ivatury \& Mas 2008).

Lyons and Scherpf (2004) indicate that individuals are underbanked for various reasons including the lack of financial knowledge of the banking systems and the expectations of having a bank account, past negative banking experiences, a lack of appropriate documentation needed to open a bank account, financial constraints and unstable living situations. Godinho and Singh (2013) suggest that underbanked consumers are considered to be financially excluded and share common demographic and socio-economic characteristics, being individuals with low employment and income, from ethnic minorities and non-English-speaking backgrounds. More specifically, underbanked consumers can also be described as those individuals situated in rural areas that are earning between R450 and R1800 per month (Falkena et al. 2004).

\section{The characteristics of cardless banking}

Cardless banking facilities allow consumers, either underbanked or banked, to electronically transfer funds using an ATM, self-service kiosk, mobile or Internet banking (Jones 2008). Moodley-Isaacs (2011) adds that cardless facilities provide consumers with access to banking services such as transferring funds to individuals regardless of whether they are banked or unbanked. In addition, Innova (2015) refers to cardless banking as a service that allows consumers to authorise another individual to withdraw money from an ATM without using a card. It can thus be concluded that cardless banking facilities are a platform that provides individuals with access to banking services without requiring the use of a card. Consumers may use other forms of cardless banking, which include ATMs, selfservice kiosks, mobile applications and Internet banking, to access their accounts and make transactions using their own personal details to gain access. There are four types of cardless banking services available, which include cardless cash withdrawal, mobile banking, Internet banking and biometric banking.
Cardless cash withdrawal is a facility through which account holders are enabled to withdraw funds from an account without the use of an eligible card (Istrate 2014:13). The sender can authorise the recipient through a secure channel such as a web portal, SMS or a call centre. According to Amalgamated Banks of South Africa (ABSA) (2015) cardless cash withdrawal can also be used to transfer money to send cash to individuals who do not have a bank account or to a consumer who has lost their card. Mobile banking is a system that allows consumers of a financial institution to conduct several financial transactions using a mobile device such as cellular phones and tablets (Asfour \& Haddad 2014:150). Unstructured supplementary service data is another form of mobile banking where consumers dial a short code to receive banking services, such as checking their bank balance or viewing transactions (Mishra \& Sahoo 2013:82).

Chavan (2013:20) defines Internet banking as the use of a computer that is connected to the Internet in order to make payment orders, transfers, exchanges and to view the status of an account. Accessing the Internet banking facility via computer requires access to the Internet as a prerequisite for successful Internet banking to take place (Bank of Queensland 2015). All major banks in South Africa provide computers at their branches to conduct Internet banking transactions and provide assistance to consumers who need it. Biometrics can be defined as a measurable physiological and behavioural characteristic that can be captured and subsequently compared with another at the time of verification (Gupta \& Sharma 2013:465). Biometric banking allows physiological characteristics such as the voice, fingerprints or iris detection of a consumer to be verified using biometric authentication software, on their mobile banking facilities in order to gain access to their accounts and perform their desired financial transactions (Bhosale \& Sawant 2012:11). The current service provider for South African social grants uses this technology to register social grant beneficiaries.

\section{South African banking institutions offering cardless banking options}

ABSA Bank developed a secure cardless cash withdrawal system called Cash Send. This service is aimed at aiding both banked and underbanked South African consumers. The system allows users to transfer funds to a recipient from their account or linked profiles using a cell phone banking application (ABSA 2015; Istrate 2014). First National Bank (FNB) also has a cardless banking service called $e$-wallet. E-wallet allows users to transfer money from an FNB transactional account to someone with a valid cell phone number using an FNB ATM, mobile banking or Internet banking (FNB 2015). Nedbank provides a similar service to its customers called Send-imali. Account holders require a valid South African mobile number in order to make transactions at a fee (NedBank 2015). InstantMoney is a payment solution that allows individuals to partake in transactional activities from a sender to a beneficiary. This service is available and accessible to any citizen and is offered by Standard Bank (Standard Bank 2014). 


\section{South African non-banking institutions offering cardless banking}

Pep (a retail store) provides cardless banking options for its Pepclub members through various retail stores, which include Shoprite, Checkers, Pep Home and Pepcell stores across the country. The service costs 9 rand per transaction. The consumers are required to give the cashiers the details of the person who is meant to receive the money as well as how much they intend to send. The sender will then receive 2 SMSs on his or her mobile phone with a withdrawal number and an access code. The sender is then required to send the receiver the 10-digit withdrawal number and the 4-digit access code and notify him or her of the amount of money he or she has sent (Pep Money 2017).

Money Market is a service provided by Shoprite and Checkers. This is a dedicated counter inside the store that allows consumers to send and receive money conveniently without the need for a bank account. The consumers that want to facilitate their financial transactions through Money Market are required to go to any Money Market counter with a South African identity book, the amount they want to send in cash and R9.99 for the transaction fee. The sender is then required to select a 4-digit PIN to receive a Money Market transfer number that is to be sent to the recipient who is intended to collect the money on the other side (Shoprite 2015).

Pick n Pay stores have collaborated with Bankserv-Africa to provide a service that will allow its customers to transfer money without the need for a bank account. The transactions are immediate as the consumer deposits cash at Pick n Pay or Boxer superstores throughout the country. A systemgenerated PIN ensures the safety of the transfer, with both the sender and the recipient having to show both the PIN and the reference number along with their South African identity book as a form of identification upon collection (Fin24 2012).

\section{Benefits of cardless banking to underbanked consumers}

Currently, card-based ATMs do not provide enough security; in the event of someone obtaining a bank account holder's bank card and PIN, the bank account holder's account can be compromised with ease. However, cardless ATMs provide a stronger authentication process to ensure the right person is accessing an account (Bhosale \& Sawant 2012). Cardless banking enhances security by eliminating the possibility of 'shoulder surfing' and card-skimming that consumers may encounter, as it removes payment data inserted into physical transaction points and ensures that consumer data is never stored on the mobile facilities on which the consumer transacts (Bhosale \& Sawant 2012).

Cardless banking allows for the convenience of performing transactions with the flexibility of performing transactions for goods and services when desired and without the need of a branch or standing in a queue (Johnson 2014). Consumers keep with familiar user interfaces that are presented through the mobile phones, which provides a level of simplicity to the process of using cardless cash withdrawals (Asfour \& Haddad 2014:145).

Complaints such as stolen or lost cards, the regeneration of new cards as a result and the general costs of maintaining the card databases are eliminated from the equation (Bhosale \& Sawant 2012). The transaction costs involved in using cardless banking are relatively low compared to those of card transactions because of lower withdrawal fees from ATMs, lower recurring payment fees and lower costs of transfers (Capitec 2018). David-West (2006) argues that apart from increasing customer convenience, self-service electronic channels such as ATMs reduce bank human transaction service costs and overall operational costs.

\section{Drawbacks of cardless banking to underbanked consumers}

David-West (2006) states that in the developing continent of Africa, Internet communication technology device imports are not only costly but also demand competent specialists for operation and maintenance. This is more prominent in the banking industry, where the core banking applications are derived from foreign technology, which creates additional expenses such as foreign training for bank staff and implementation specialists. This is a drawback for underbanked consumers for they would require more knowledge for the operational aspects of the interfaces of such devices, which they do not possess.

Fraudulent activities may occur using both high- and lowtechnology means (David-West 2006). Yeboah-Boateng and Amanor (2014:299) define phishing as when an online user is deceived into disclosing his or her confidential information such as login details or password or when a consumer receives an SMS stating that a bank official will contact them to verify or update their banking details, which is sent to the consumer by an account hacker. The hacker then calls the consumer under the pretext that he or she is the bank official and commits fraudulent activity with their banking details.

SIM swap fraud is a scam whereby the hacker contacts the consumer's network operator (such as MTN, Vodacom or Cell C) and asks for their cell phone number to be reassigned to a new SIM card in order to gain access to confidential information such as their mobile banking 'one-time' PIN used to complete financial transactions (Muller \& Uhde 2013).

\section{Factors influencing consumers' perceptions of cardless banking}

In this section, the research shall discuss the factors that influence consumers' individual perceptions. These factors shall be applied towards adoption of cardless banking services. The factors that are to be discussed are as follows: 
relative advantage, compatibility, trialability, observability and complexity.

\section{Relative advantage of cardless banking}

Venkatesh and Bala (2008) and Kautz and Larsen (2000) define perceived relative advantage as the extent to which an innovation is seen as being better than the idea it supersedes. To further support this notion, Atkinson (1957) gives an application of this definition by stating what the advantages may be in relation to social status, the economy or other factors. Simply put, innovations that seem to be advantageous when compared to others, both current and prior, are likely to be taken on.

\section{Compatibility of cardless banking}

Venkatesh and Bala (2008) define compatibility as the degree to which an invention is seen as consistent with the existing values, past experiences and needs of likely adopters. Atkinson (1957:364) elaborates by stating that adoption is more likely when the innovation is consistent with the sociocultural, economic and philosophical belief structure of the consumers. Compatibility of cardless banking services with underbanked consumers' norms, values and ways of working as suggested by Greenhalgh et al. (2004:594-596) is an additional element of successful absorption.

\section{Trialability of cardless banking}

Venkatesh and Bala (2008) and Kautz and Larsen (2000:15) discuss trialability as the ability of an invention to be tested to a certain extent. However, Atkinson (1957) adds that if the innovation can be tried before adoption, then its adoption would be more rapid than those that cannot be tried. Late adopters use the experience of their peers as an indirect trial of the innovation. Thus, underbanked consumers would be more willing to want to experiment and try out the system before fully adopting it. Underbanked consumers who are unable to experiment will therefore rely on the user experiences encountered by the early adopter in assessing their perception on cardless banking services.

\section{Observability of cardless banking}

An innovation is adopted more easily if the benefits are visible to the intended adopters. Initiatives that make more of the benefits of the innovation more visible essentially improve the chances of it being accepted and adopted (Kautz \& Larsen 2000; Greenhalgh et al. 2004; Venkatesh \& Bala 2008). It is thus possible to suggest that should underbanked consumers be able to perceive the benefit of utilising cardless banking systems more easily, this would bring about a positive impact on their intention to use the services offered.

\section{Complexity of cardless banking}

Atkinson (1957) refers to complexity as the extent to which an innovation is seen as relatively difficult to use and understand.
Atkinson (1957) further elaborates that those innovations that are seen as complex or hard to use are less likely to be accepted and adopted. Venkatesh and Bala (2008) and Kautz and Larsen (2000) also define complexity as the degree to which something is perceived as relatively difficult to understand and use. Cardless banking services that are implemented by institutions thus need to be perceived by underbanked consumers as simple to understand and use. These systems need to be user-friendly and practical for underbanked consumers to induce intention of adoption for the services.

\section{Research paradigm and methodology}

Thomas (2003:1) explains that a positivistic research paradigm is based on numbers and mathematical measurements of characteristics shown by individuals and events. Data is composed by using amounts and numbers and therefore is quantitative in nature. Kumar (2011:168) adds that positivistic research lets researchers explore, determine, combine, intensify and quantify attitudes to unlike events or objects to arrive at a conclusion about overall attitudes.

When conducting research, the methods of data collection and data analysis that would be most suitable for the chosen methodology need to be determined. Data collection is the systematic method of collecting and evaluating information about variables of interest, which will enable a researcher to resolve stated research scenarios, test hypotheses and evaluate outcomes (Spasford \& Jupp 2006:157). Harrel and Bradley (2009:2) assert that the researcher must make sure that the data collected is obtained in a standardised and scientific manner, as this will yield high quality, reliable research findings. Both primary and secondary data were collected for this study. For data to be analysed, the reliability and validity of the measuring instrument need to be assessed beforehand. Following that, the descriptive statistics such as the mean, standard deviation and frequency distributions have to be calculated to condense the sample data distribution.

\section{Data collection}

For this study a broad secondary literature search (secondary data) was conducted to describe the various forms of cardless banking systems as well as to describe the perceptions of the underbanked consumers towards these systems. The hypothesised relationships are supported by the literature review conducted using secondary sources. The literature search was conducted through the Nelson Mandela Metropolitan University network libraries, online databases (Emerald Insight and EBSCOhost), Google searches and Science Direct. Hair et al. (2007:192) note that primary data is collected via observations, interviews and questionnaires. The collection of primary data calls for decisions on population sampling techniques and sample size, as well as data collection and statistical analysis. 


\section{Sample}

The sample in this study consists of underbanked consumers within the Nelson Mandela Metropole, Eastern Cape, who reside in the northern and township areas. The sample was made up of a total of 200 respondents. However, of the 200 distributed questionnaires, only 178 were recovered. This gives an $89 \%$ response rate. With only 175 questionnaires being useable, the effective response calculated is $87.5 \%$. Two non-probability sampling techniques were used for this study - convenience and snowball sampling. According to Struwig and Stead (2013:82) a convenient sample is selected from elements of a population that are easily accessible. Fieldworkers who were familiar with the study, the areas selected as well as the language spoken collected the data using questionnaires. All questionnaires were facilitated by the fieldworkers to ensure that the respondents understood the questions.

\section{Measuring instrument and scale development}

The measuring instrument employed in this study consisted of a cover letter and six sections. The cover letter included a detailed description of the aim and purpose of the study as well as the nature of the information requested from the respondents taking part in this study. The cover letter also included a promise of anonymity and instructions on how to complete the questionnaire. The cover letter was drafted with the intention to make it easy to understand as the respondents who would read it would most likely have a limited literacy level. The first part of the questionnaire (Section A) requested general information that would cover the demographical aspect of the study; this included age range, ethnicity, level of education and the industry in which they plied their trade. The subsequent section, Section B, contained questions measuring underbanked consumers' perceptions of cardless banking and consequently their intention to adopt cardless banking.

A five-point Likert scale was used to allow the respondents to indicate their extent of agreement or disagreement. The scale started with ' 1 ' being the most extreme disapproval, or strongly disagreeing with the notion. The scale ended with ' 5 ' being the most extreme approval, or strongly agreeing with the notion. These scales used in the study were adapted from various authors (Ajzen 1991; Atkinson 2007; Moore \& Benbasat 1991; Ntemana \& Olatokun 2012; Venkatesh \& Bala 2008) and renamed and reworded to suit the context of the study.

\section{Validity and reliability of the measuring instrument}

Hamdan, Badrullah and Shahid (2011), Saleh and Khine (2011), Creswell (2008) and Kerlinger and Lee (2000) all state that validity is achieved when a variable measures what it is supposed to measure meaningfully. Validity was determined using an exploratory factor analysis, where factor loadings greater than 0.5 were considered valid. Reliability demonstrates the extent of consistency between scale items of a variable (Bryman \& Bell 2007:63). Zikmund et al. (2012) state that internal consistency is attained when items on the scale are independent measures of the same construct and as a result correlate with one another. Cronbach's alpha coefficients were used to establish the reliability of the data received. Coefficients greater than 0.7 are considered an acceptable measure of reliability (Kabir 2013:102).

\section{Data analysis}

The responses were captured on a Microsoft Excel spreadsheet in preparation for statistical analysis using Statistica 10. To describe or summarise information about a sample or population, descriptive statistics are used to provide statistical summaries of data. The purpose of these statistics is to provide a rational or logical conclusion of large amounts of data (Struwig \& Stead 2013:165; Zikmund et al. 2012). Inferential statistics make it possible to generalise the findings from the sample to the population (Struwig \& Stead 2013:167). Parametric statistics were employed using Pearson's productmoment correlation coefficient as well as the multiple regression analysis to determine the nature and strength of relationships between variables.

\section{Results \\ Demographic information}

From Table 1, it is evident that the majority (55.43\%) of the respondents were male while $44.57 \%$ of the respondents were female. A majority of the respondents were aged between 20 and 29 years while respondents over 60 years of age only made up $4 \%$ of the sample. In terms of ethnicity, black respondents represented $67.43 \%$ of the sample. Mixed-race people made up $17.71 \%$ of the respondents, while white people made up $6.86 \%$. Asian people were least represented, making up only $4.00 \%$ of the total sample.

The respondents held various occupations; however, the large majority $(38.68 \%)$ indicated that they had jobs other than what was indicated on the measuring instrument. The most common occupations were cleaners (10.86\%), cashiers $(9.14 \%)$, domestic workers $(6.29 \%)$ or petrol attendants (5.71\%). Most of the respondents (31.43\%) earned between R1500 and R2500 per month. A significant percentage of respondents (23.43\%) earned less than R1500 a month, and only $18.29 \%$ of the respondents earned more than R4000 per month. Table 1 also indicates the frequency of banking service usage. Most of the respondents (49.14\%) made use of banking services at least once a week. Another cluster of respondents $(31.43 \%)$ only used them once a month. Of the respondents, $4 \%$ used banking services every day while less than $2 \%$ $(1.71 \%)$ reported never using banking services at all. Most of the respondents $(59.43 \%)$ indicated that they withdrew cash as their main activity, while sending and receiving funds using cardless services made up $23.43 \%$ of the survey responses. Respondents' responses indicated that only $6.29 \%$ performed deposits and $5.71 \%$ did cash transfers. Commercial 
TABLE 1: Demographic information pertaining to the respondents.

\begin{tabular}{|c|c|c|}
\hline Variable & Frequency & Percentage \\
\hline \multicolumn{3}{|l|}{ Gender } \\
\hline Male & 97 & 55.43 \\
\hline Female & 78 & 44.57 \\
\hline Total & 175 & 100.00 \\
\hline \multicolumn{3}{|l|}{ Age } \\
\hline Younger than 20 & 23 & 13.14 \\
\hline $20-29$ & 69 & 39.43 \\
\hline $30-39$ & 39 & 22.29 \\
\hline $40-49$ & 18 & 10.29 \\
\hline $50-59$ & 19 & 10.86 \\
\hline Older than 60 & 7 & 4.00 \\
\hline Total & 175 & 100.00 \\
\hline \multicolumn{3}{|l|}{ Ethnicity } \\
\hline Asian people & 7 & 4.00 \\
\hline Black people & 118 & 67.43 \\
\hline Mixed race people & 31 & 17.71 \\
\hline Indian people & 4 & 2.29 \\
\hline White people & 12 & 6.86 \\
\hline Not willing to say & 3 & 1.71 \\
\hline Total & 175 & 100.00 \\
\hline \multicolumn{3}{|l|}{ Occupation } \\
\hline Baker & 3 & 1.71 \\
\hline Bus inspector & 1 & 0.57 \\
\hline Car guard & 4 & 2.29 \\
\hline Cashier & 16 & 9.14 \\
\hline Child minder & 9 & 5.14 \\
\hline Cleaner & 19 & 10.86 \\
\hline Community cleaner & 6 & 3.43 \\
\hline Construction worker & 5 & 2.86 \\
\hline Domestic worker & 11 & 6.29 \\
\hline Driver & 3 & 1.71 \\
\hline Gaartjie (Taxi conductor) & 8 & 4.57 \\
\hline Hairstylist assistant & 4 & 2.29 \\
\hline Merchandiser & 5 & 2.86 \\
\hline Meter reader & 2 & 1.14 \\
\hline Petrol attendant & 10 & 5.71 \\
\hline School caretaker & 1 & 0.57 \\
\hline Other & 68 & 38.86 \\
\hline Total & 175 & 100.00 \\
\hline \multicolumn{3}{|l|}{ Income (rand) } \\
\hline Less than 500 & 18 & 10.29 \\
\hline Less than 1500 & 41 & 23.43 \\
\hline Less than 2500 & 55 & 31.43 \\
\hline Less than 3500 & 29 & 16.57 \\
\hline More than 4000 & 32 & 18.29 \\
\hline Total & 175 & 100.00 \\
\hline \multicolumn{3}{|l|}{ Frequency of use } \\
\hline Every day & 7 & 4.00 \\
\hline Once a week & 86 & 49.14 \\
\hline Once a month & 55 & 31.43 \\
\hline Seldom & 24 & 13.71 \\
\hline Never & 3 & 1.71 \\
\hline Total & 175 & 100.00 \\
\hline \multicolumn{3}{|l|}{ Transactions performed } \\
\hline Cash withdrawals & 104 & 59.43 \\
\hline Cash transfer & 10 & 5.71 \\
\hline Balance enquiries & 1 & 0.57 \\
\hline Account payments & 8 & 4.57 \\
\hline Deposits & 11 & 6.29 \\
\hline
\end{tabular}

Table 1 continues $\rightarrow$
TABLE 1 (Continues...): Demographic information pertaining to the respondents.

\begin{tabular}{lcc}
\hline Variable & Frequency & Percentage \\
\hline Sending and receiving funds using cardless cash withdrawal & 41 & 23.43 \\
Total & 175 & 100.00 \\
Institutions used & & \\
Commercial banks other than Capitec & 97 & 55.43 \\
Non-commercial banking institution & 41 & 23.43 \\
Capitec Bank & 37 & 21.14 \\
Total & 175 & 100.00 \\
\hline
\end{tabular}

TABLE 2: Factor structure of the independent and dependent variables.

\begin{tabular}{|c|c|c|c|c|c|}
\hline Variable & CPLX & TRIA & COMP/ADV & INTN & N/A \\
\hline CPLX006 & 0.738922 & 0.019801 & 0.176988 & 0.416680 & 0.086281 \\
\hline CPLX001 & 0.725325 & 0.175093 & 0.400681 & 0.012905 & 0.143832 \\
\hline CPLX007 & 0.722188 & 0.151604 & 0.104427 & 0.252867 & 0.264068 \\
\hline CPLX005 & 0.704198 & 0.055164 & 0.077200 & 0.252637 & 0.412090 \\
\hline CPLX002 & 0.679082 & 0.122843 & 0.270512 & 0.391700 & 0.149179 \\
\hline OBSV002 & 0.644842 & 0.056961 & 0.480968 & 0.247529 & 0.008415 \\
\hline TRIA006 & 0.057929 & 0.824789 & 0.080749 & 0.265682 & 0.034506 \\
\hline TRIA001 & 0.038113 & 0.743926 & 0.350768 & 0.026494 & 0.041007 \\
\hline TRIA003 & 0.257035 & 0.719507 & 0.003119 & 0.345829 & 0.163997 \\
\hline COMP005 & 0.223805 & 0.047939 & 0.691345 & 0.390450 & 0.011697 \\
\hline RADV007 & 0.212026 & 0.159784 & 0.679850 & 0.321965 & 0.121478 \\
\hline COMP002 & 0.130816 & 0.058992 & 0.669397 & 0.020743 & 0.270161 \\
\hline RADV004 & 0.208124 & 0.106005 & 0.659732 & 0.123493 & 0.445418 \\
\hline COMP001 & 0.384531 & 0.180758 & 0.615186 & 0.439170 & 0.066625 \\
\hline RADV005 & 0.360005 & 0.206893 & 0.612474 & 0.155604 & 0.333208 \\
\hline INTN002 & 0.248332 & 0.161256 & 0.183477 & 0.781864 & 0.157472 \\
\hline INTN004 & 0.165974 & 0.198254 & 0.145400 & 0.760795 & 0.288299 \\
\hline INTN001 & 0.249796 & 0.201698 & 0.212552 & 0.702784 & 0.259781 \\
\hline INTN003 & 0.348809 & 0.293452 & 0.196903 & 0.679720 & 0.226996 \\
\hline RADV002 & 0.107849 & 0.117279 & 0.195177 & 0.401708 & 0.709233 \\
\hline OBSV005 & 0.266749 & 0.028276 & 0.204017 & 0.415716 & 0.613083 \\
\hline RADV006 & 0.368430 & 0.091202 & 0.302452 & 0.401006 & 0.599754 \\
\hline TRIA002 & 0.423783 & 0.103789 & 0.194913 & 0.156451 & 0.575663 \\
\hline CPLX003 & 0.527307 & 0.103921 & 0.209480 & 0.320488 & 0.445993 \\
\hline OBSV003 & 0.473602 & 0.134076 & 0.226971 & 0.198031 & 0.392744 \\
\hline COMP004 & 0.408486 & 0.092949 & 0.434417 & 0.547893 & 0.304734 \\
\hline RADV003 & 0.301926 & 0.264291 & 0.563039 & 0.359512 & 0.263170 \\
\hline CPLX004 & 0.539000 & 0.162506 & 0.327312 & 0.298711 & 0.262916 \\
\hline INTN005 & 0.207838 & 0.234840 & 0.479535 & 0.591462 & 0.227688 \\
\hline RADV001 & 0.418856 & 0.196680 & 0.282679 & 0.472682 & 0.220803 \\
\hline OBSV001 & 0.524970 & 0.302920 & 0.275037 & 0.111515 & 0.188896 \\
\hline OBSV004 & 0.476270 & -0.056556 & 0.223036 & 0.376785 & 0.119158 \\
\hline EXPL.VAR & 5.913698 & 2.493042 & 4.711331 & 5.249786 & 3.253302 \\
\hline PRP.TOTL & 0.184803 & 0.077908 & 0.147229 & 0.164056 & 0.101666 \\
\hline
\end{tabular}

Note: Bold texts represent factor loadings greater than 0.6 where more than two items loaded together were considered for further analysis.

CPLX, complexity; TRIA, trialability; OBSV, observability; COMP, compatibility; RADV, relative advantage; INTN, intentions; COMP/ADV, compatible advantage; N/A, not considered for further statistical analysis; EXPL.VAR, Explained variance; PRP.TOTL, proportion of total variance.

banks were commonly used by most of the respondents (55.43\%), and few respondents indicated that they made use of Capitec Bank. Non-commercial banking institutions like Pep and Shoprite were used by $23.43 \%$ of the respondents.

\section{Results of the validity and reliability assessments}

An exploratory factor analysis was undertaken to assess the validity of the independent and dependent variables investigated in this study. The resulting factor structure can be found in Table 2 . 
TABLE 3: Reliability assessment.

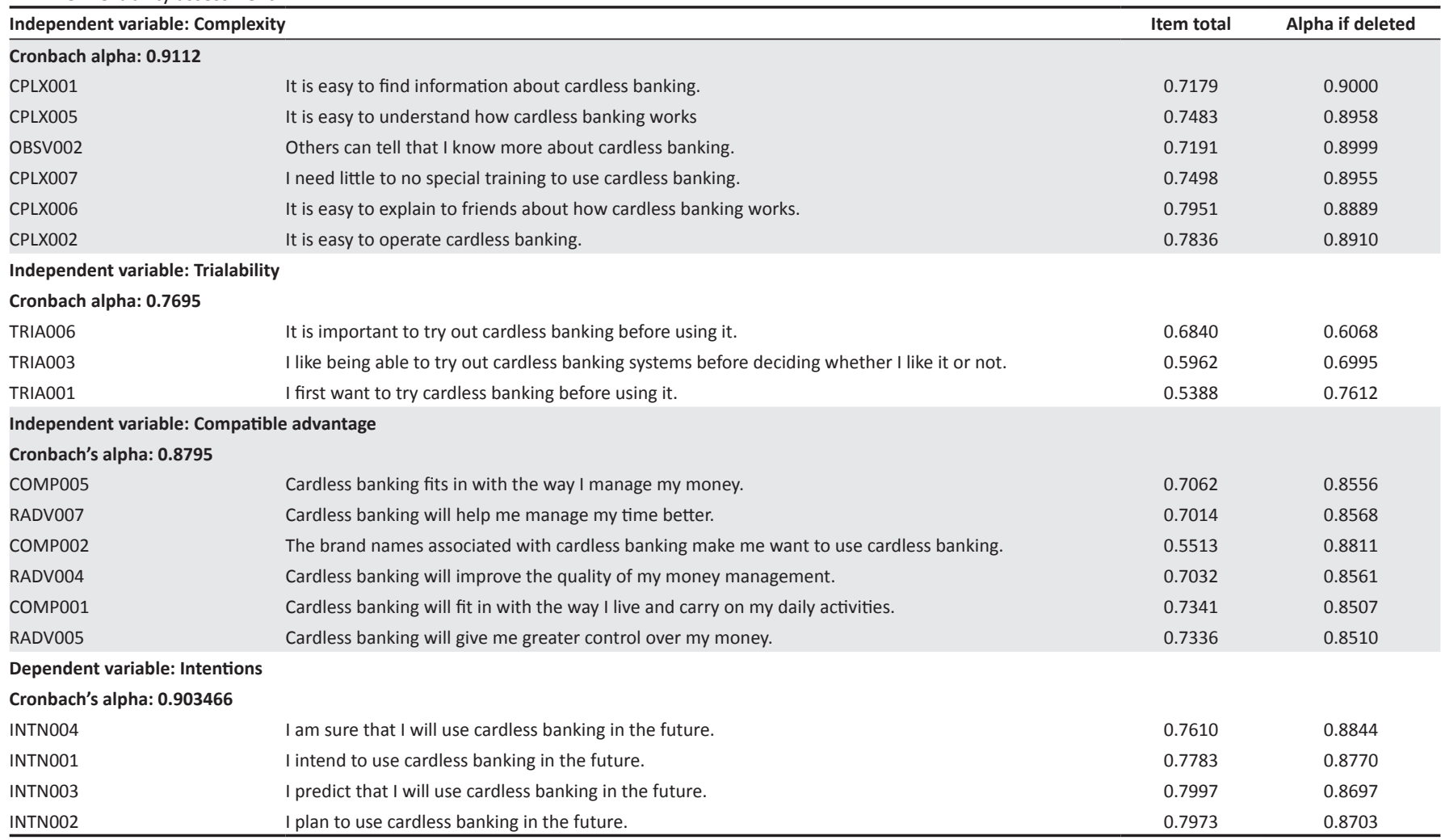

Factor loadings greater than 0.6 where more than two items loaded together were considered for further analysis. Thus, only three of the original five factors could be considered for further analysis, namely complexity, trialability and compatible advantage (relative advantage and compatibility). Table 3 provides results of the reliability assessments conducted using Cronbach's alpha coefficients.

From Table 3 it is evident that of the seven items considered as a measurement for complexity, only five items loaded. One item measuring observability (OBSV002) loaded onto the factor complexity and was considered as part of the reoperationalisation of complexity. The loadings for this factor were all above 0.644842; the Cronbach's alpha coefficient was 0.9112 , and thus the items measuring complexity can be considered as valid and reliable. Three of the original six items measuring trialability loaded together, resulting in factor loadings between 0.719507 and 0.824789 and a Cronbach's alpha coefficient of 0.7695 , which provides evidence of both validity and reliability. Several items measuring both relative advantage and compatibility loaded together. After considering the relationships between and operational definitions of these items, the factors were reoperationalised as compatible advantage. The factor loadings for compatible advantage ranged between 0.612474 and 0.691345 and a Cronbach's alpha coefficient of 0.8795 , thus providing sufficient evidence of validity and reliability. The dependent variable intentions was also considered valid and reliable, with factor loadings above 0.679720 and a Cronbach's alpha coefficient of 0.903466 .

Pearson's moment correlation coefficient was undertaken to determine the strength and direction (whether positive or
TABLE 4: Pearson's correlation and multiple regression results.

\begin{tabular}{lccccccc}
\hline Variable & CPLX & COMP & TRIA & INTN & \multicolumn{3}{c}{$\boldsymbol{R}^{2}=\mathbf{0 . 5 5 3 9}$} \\
\cline { 6 - 9 } & & ADV & & & $\mathbf{b}^{*}$ & $\mathbf{b}$ & $\boldsymbol{p}$ \\
\hline Complexity & $\mathbf{1 . 0 0 0 0}$ & 0.6605 & 0.3896 & 0.6619 & 0.3947 & 0.3717 & $0.0000^{*}$ \\
Compatible advantage & 0.6605 & $\mathbf{1 . 0 0 0 0}$ & 0.4504 & 0.6301 & 0.2559 & 0.2646 & $0.0004^{*}$ \\
Trialability & 0.3896 & 0.4504 & 1.0000 & 0.5211 & 0.2521 & 0.2879 & $0.0000^{*}$ \\
Intention & 0.6619 & 0.6301 & 0.5211 & 1.0000 & - & - & - \\
\hline
\end{tabular}

Note: Bold data depicts correlation.

CPLX, complexity; COMP ADV, compatible advantage; TRIA, trialability; INTN, intention. $*, p<0.001$.

negative) of the relationship between the variables, and a multiple regression analysis was used to determine the extent to which the complexity, trialability and compatible advantage of cardless banking affects underbanked consumers' intentions to adopt cardless banking (Struwig \& Stead 2013:168-169). The results of both the Pearson correlation and multiple regression analysis are depicted in Table 4 .

From Table 4 it is evident that there is a positive relationship between the independent and dependent variables. The strongest relationship can be seen between the independent variable complexity and the dependent variable intentions (0.6619) and between complexity and compatible advantage (0.6605). The weakest relationship was found to be between complexity and trialability (0.3896). Because there is a positive relationship between the variables, a multiple regression analysis was conducted to determine whether these factors exhibit a significant influence on whether underbanked consumers intend to make use of cardless banking.

The results of the multiple regression analysis show that the independent variables explain $55.39 \%$ of the variance in the 
dependent variable $\left(R^{2}=0.5539\right)$. The strongest relationship exists between complexity and intentions (0.3717; $p<0.001)$, confirming that if consumers perceive cardless banking to be simple to use, understand and operate, then they are more likely to have intentions to adopt cardless banking. Significant influences were found between the independent variables trialability $(0.2879 ; p<0.001)$ and compatible advantage $(0.2646$; $p<0.001)$ and the intentions to make use of cardless banking. In other words, if underbanked consumers have the option of trying cardless banking without obligation before committing to it, they are more likely to adopt cardless banking. Furthermore, if cardless banking fits into and improves the lifestyle and needs of underbanked consumers, they are also more likely to make use of cardless banking.

\section{Discussion of findings}

The demographic findings of this study contradict literature that indicates that underbanked consumers are younger and mostly use cardless banking to check account balances (Global Findex 2014; Gross et al. 2012; Kostov et al. 2014). Only $13 \%$ of the respondents were younger than 20 , and the majority of the respondents were aged between 20 and 39 $(61.72 \%)$. In addition, the findings confirm that the respondents can indeed be considered underbanked, as a significant percentage of the respondents visited a bank or used cardless banking once a month $(31.43 \%)$ or once a week (49.14\%), most likely to withdraw their wages, as the most frequent banking activity was cash withdrawal (59.43\%) or sending or receiving funds through cardless cash withdrawal $(23.43 \%)$ and not to check account balances $(0.57 \%)$.

The Pearson's correlations reported positive correlations between all the variables, particularly between the independent variable complexity and the dependent variable intentions (0.6619). This indicates that if cardless banking were to be less complex and more simplified to use and understand, underbanked consumers would be willing to make use of it. Similar results were found between the independent variables trialability and compatible advantage and the dependent variable, indicating that if underbanked consumers were able to try cardless banking before deciding whether to make use of it and if it is consistent with their daily operations and beliefs and improves their lifestyle, they are more likely to have intentions to make use of cardless banking. These results were further confirmed through a multiple regression analysis, indicating that if underbanked consumers have positive perceptions about the complexity $(0.3717 ; p<0.001)$, the compatible advantage $(0.2646 ; p<0.001)$ and the trialability $(0.2879 ; p<0.001)$ of cardless banking, then they are more likely to have intentions to make use of cardless banking.

\section{Recommendations}

The following is recommended to financial institutions who intend on capturing the underbanked consumer segment, the National Treasury and other governmental institutions who wish to increase financial inclusion to underbanked consumers and especially to SASSA when considering an alternative payment method for social grant beneficiaries.

Cardless banking needs to fit in better with the way underbanked consumers live and carry out their daily activities. Consumers need to gain greater control over and improve their quality of money management through the usage of the cardless banking service that is being offered.

In order to positively influence the perceptions of the underbanked consumers, financial and non-financial institutions offering cardless banking should ensure that it is easy to find information on and operate. Little to no special training should be required in order to use cardless banking, and it must be easy to explain to one's friends and family how it works, if one understands how the cardless banking service works. Gaining accessibility to these services should also be simplified. A characteristic of the current service provider administering the social grants is their ability to manage the social grants beneficiary database using biometric technology, where beneficiaries are identified by scanning their thumbprints. Commercial banks have started using this technology and are able to verify the identity of their consumers by scanning their thumbprints based on the Department of Home Affairs database, because South African residents are required to register their fingerprints when applying for a South African identity book. This will simplify the registration process for underbanked consumers and simultaneously minimise fraudulent activity associated to social grants such as unauthorised withdrawals using a beneficiary's SASSA card.

In addition, underbanked consumers or social grant beneficiaries should be allowed to try cardless banking before using it to experience its benefits in order to assess how suitable it is to their individual circumstances without the risk of loss or barriers should they not prefer it. If they are unable or unwilling to use it on a trial basis, they should be able to observe its benefits. This could be achieved through mobile application tutorials, campaigns or advertisements.

As indicated in the study, underbanked consumers receive a monthly income that is below R2500. Cost is therefore a major determinant in the selection of financial institutions. Nonbanking institutions that offer cardless banking services have identified the need and addressed it by offering flat rates for transactions at affordable prices that are processed through their services. Financial institutions, specifically banks, should also look into ways in which they can address the low transaction costs that are required by underbanked consumers in order to enhance their banking experience and better service that market.

The need for secure facilities and transactional processes is also a key determinant that underbanked consumers consider when selecting cardless banking service providers. Financial institutions should ensure that the safety of their processes and facilities is highlighted in their communication for underbanked consumers. Instances of smishing and phishing are factors that deter underbanked consumers 
from using the cardless banking services being offered by financial institutions. It is therefore important for financial institutions to ensure that measures are placed in order to decrease the vulnerabilities of their cardless banking services. This is particularly important as there are safer and more rigid security measures provided through banking facilities, which require two-medium authentication (e.g. transactions on Internet banking must be confirmed through a cell phone application or SMS); however, when a third party is involved, such as a retail store or cell phone service provider, that security is not entirely within the bank's control. It is therefore recommended that non-banking institutions that offer cardless banking formalise and strengthen their internal security measures or perhaps collaborate with banking institutions to improve their security measures.

\section{Limitations of the study}

The current study was limited to respondents who were identified by means of convenience sampling. The respondents were underbanked consumers who were sourced within the Nelson Mandela Metropole, Eastern Cape, and resided in the northern and township areas. Therefore, because convenience sampling was used to identify the respondents in this study, the findings cannot not be generalised to the entire underbanked population.

\section{Conclusion}

Before government institutions introduce new methods of payment to social grant holders it is important to first determine their perceptions thereof. Furthermore, to improve financial inclusion, the features of the existing financial products and services that are offered in the financial services sector should be trialable, observable and provide benefits that are compatible with their current lifestyles.

\section{Acknowledgements Competing interests}

The author declares that she has no financial or personal relationships that may have inappropriately influenced her in writing this article.

\section{References}

ABSA, 2015, Absa Cash Send, viewed 28 February 2015, from http://www.absa.co.za/ absacoza/individual/ways-to-bank/anytime,-anywhere/cellphonebanking/cashsend.

Atkinson, J.W., 1957, 'Motivational determinants of risk-taking behavior', Psychological Review 64(1), 359-372. https://doi.org/10.1037/h0043445

Atkinson, N.L., 2007, 'Developing a questionnaire to measure perceived attributes of eHealth innovations', American Journal of Health Behaviour 31(6), 612-621. https://doi.org/10.5993/AJHB.31.6.6

Ajzen, I., 1991, 'The theory of planned behaviour', Organizational Behaviour and Human Decision Processes 50(2), 179-211. https://doi.org/10.1016/07495978(91)90020-T

Asfour, H.K. \& Haddad, S.I., 2014, 'The impact of mobile banking on enhancing customers' e-satisfaction: An empirical study on commercial banks in Jordan' International Business Research 7(10), 145-169. https://doi.org/10.5539/ibr. v7n10p145

Bångens, L. \& Söderberg, B., 2008, 'Mobile banking -financial services for the unbanked?', The Swedish Program for ICT in Developing Regions: Proceedings of
the Ninth International Network Conference, viewed n.d. from https://spider1. the Ninth International Network Conference, viewed n.d., from https://spider1.
blogs.dsv.su.se/wp-content/blogs.dir/362/files/2016/11/Spider-ICT4D-Series-2Mobile-banking-financial-services-for-the-unbanked.pdf.
Bank of Queensland, 2015, Internet Banking Requirements, viewed 01 April 2015, from http://www.boq.com.auonline_enhancedlB_technical.htm.

Bhosale, S.T. \& Sawant, B.S., 2012, 'Security in e-banking via cardless biometric ATMs', International Journal of Advanced Technology and Engineering Research 2(4), 9-12.

Bryman, A. \& Bell, E., 2007, Business research methods, 2nd edn., Oxford, New York.

Capitec, 2018, Capitec Bank: Transact, viewed 02 September 2018, from https:// www.capitecbank.co.za/global-one/transact/fees?

Chavan, J., 2013, 'Internet banking: Benefits and challenges in an emerging economy', International Journal of Research in Business 1(1), 19-26.

Community Survey, 2016, Stats South Africa: Statistical release, viewed 26 April 2017, from http://www.statssa.gov.za/?page_id=6283.

Creswell, J.W., 2008, Educational research: Planning, conducting, and evaluating quantitative and qualitative research, Prentice Hall, Upper Saddle River, NJ.

Dasnois, A. \& Maregele, B., 2017, Constitutional court calls SASSA to account, viewed 02 March 2017, from http://www.groundup.org.za/article/constitutional-courtcalls-sassa-account.

David-West, O., 2006, 'Information and communications technology-based banking operations and services applications, impacts and challenges', African Journal of Computing and ICTS 5(2), 27-39.

Demirgüç-Kunt, A. \& Klapper, L.F., 2012, 'Measuring financial inclusion: The global findex database', World Bank Policy Research, viewed 25 February 2017, from https://papers.ssrn.com/sol3/papers.cfm?abstractid2043012.

Falkena, H., Davel, G., Hawkins, P., Llewellyn, D., Luus, C., Masilela, E. et al., 2004, Task group report for the National Treasury and the South African Reserve Bank, National Treasury, South Africa.

Figart, D.M., 2013, 'Institutionalist policies for financial inclusion', Journal of Economic Issues 47(4), 873-894. https://doi.org/10.2753/JEI0021-3624470404

FNB, 2015, Cardless Cash Withdrawal, viewed 25 May 2015, from https://www.fnb. co.za/promotions/cardlesscashwithdrawal/index.html.

Fin24, 2012, Pick $n$ Pay in new cash transfer option, viewed 09 February 2012, from https://www.fin24.com/companies/retail/pick-n-pay-in-new-cash-transferoption-20120118.

Global Findex, 2014, Measuring financial inclusion around the world, viewed 22 March 2015 from http://www.worldbank.org/en/programs/globalfindex.

Godinho, V. \& Singh, S., 2013, 'Technology enabled financial inclusion and evidencebased policy for the underbanked: A study of remote indigenous Australia', Policy Brief 8(1).

Greenhalgh, T., Robert, G., Macfarlane, F., Bate, P. \& Kyriakidou, O., 2004, 'Diffusion of innovations in service organizations: Systematic review and recommendations' The Milbank Quarterly 82(4), 581-629. https://doi.org/10.1111/j.0887378X.2004.00325.X

Gross, M.B., Hogarth, J.M. \& Schmeiser, M.D., 2012, 'Use of financial services by the unbanked and underbanked and the potential for mobile financial services adoption', Federal Reserve Bulletin 98(4), 1-20.

Gupta, N. \& Sharma, A., 2013, 'Review of biometric technologies used for ATM security', International Journal of Engineering and Innovative Technology 3(2), 460-465.

Hair, J.F., Money, A.H., Page, M. \& Samouel, P., 2007, Research methods for business, John Wiley, West Sussex.

Hamdan, S., Badrullah, B. \& Shahid, M., 2011, 'Confirmatory factor analysis for testing validity and reliability in the study of education', Australian Journal of Basic and Applied Sciences 5(12), 1098-1103.

Harrel, M.C. \& Bradley, M.A., 2009, Data collection methods semi-structured interviews and focus groups, National Defense Research Institute, Santa Monica, pp. 1-148.

Innova, 2015, iMobile bank cardless cash, viewed 26 July 2015, from http://www. innova.com.tr/pdfs/9f550ad5-c61d-423f-b17b875a73b73df2iMobileCardlessCas hEn.pdf.

Istrate, C., 2014, 'Cardless withdrawal system for mobile banking applications', Journal of Mobile, Embedded and Distributed Systems 5(1), 11-16.

Ivatury, G. \& Mas, I., 2008, The early experience with branchless banking, viewed 25 November 2016, from https://papers.ssrn.com/sol3/papers.cfm?abstractid=1655257.

Johnson, R., 2014. Cardless cash: The future of ATMs? viewed 02 September 2018 from https://www.ncr.com/company/blogs/financial/cardless-cash-the-futureof-atms.

Jones, C., 2008, Absa debuts cardless ATM, viewed 25 May 2015, from http://www. itweb.co.za/index. .php?option=com content\&view=article\&id=10286

Kabir, M., 2013, 'Factors influencing the usage of mobile banking: Incident from a developing country', World Review of Business Research 3(3), 96-114.

Kautz, K. \& Larsen, E.Ä., 2000, 'Diffusion theory and practice', Information Technology and People 13(1), 11-26. https://doi.org/10.1108/09593840010312726

Kerlinger, F.N. \& Lee, H.B., 2000, Foundations of behavioural research, 4th edn., Harcourt College, New York.

Kostov, P., Arun, T. \& Annim, S., 2014, 'Banking the unbanked: The Mzansi intervention in South Africa', Indian Growth and Development Review 7(2), 118-141. https:// doi.org/10.1108/IGDR-11-2012-0046

Kumar, R., 2011, Research methodology: A step-by-step guide for beginners, 3rd edn., Sage, London.

Lyons, A.C. \& Scherpf, E., 2004, 'Moving from unbanked to banked: Evidence from the Money Smart program', Financial Services Review 13(3), 215-231. 
Maphanga, C., 2018, SAPO confident SASSA beneficiaries will be paid on time, viewed 02 September 2018, from https://www.news24.com/SouthAfrica/News/sapoconfident-sassa-beneficiaries-will-be-paid-on-time-20180731.

Mishra, S. \& Sahoo, D., 2013, 'Mobile banking adoption and benefits towards customers service, Special Issue of International Journal on Advanced Computer Theory and Engineering 2(1), 78-83.

Moodley-Isaacs, N., 2011, Use your cellphone to draw cash, viewed 29 November 2016, from http://www.iol.co.za/personal-finance/my-money/banking/use-yourcellphone-to-draw-cash-1062775.

Moore, G.C. \& Bensabat, I., 1991, 'Development of an instrument to measure the perceptions of adopting an information technology innovation', Information Systems Research 2(3), 192-222. https://doi.org/10.1287/isre.2.3.192

Muller, O. \& Uhde, A., 2013, 'Cross-border bank lending: Empirical evidence on new determinants from OECD banking markets', Journal of International Financial Markets, Institutions and Money 23(1), 136-162. https://doi.org/10.1016/j. intfin.2012.09.004

Nedbank, 2015, Nedbank sending money, viewed 28 February 2015, from https:// www.nedbank.co.za/website/content/products/product detail new.asp?SubSu www.nedbank.co.za/website/content/products/
bcatid $=6705$ andSubcatid $=709$ andProductID $=660$.

Ntemana, T.J. \& Olatokun, W., 2012, 'Analysing the influence of diffusion of innovation attributes on lecturers' attitude towards information and communication technologies', Human Technology 8(2), 179-197. https://doi.org/10.17011/ht/ urn.201211203034

Pep Money, 2017, Pep Money, viewed 02 March 2017, from http://www.pepstores. com/pep-money.

Prior, F. \& Santomá, J., 2010, 'Banking the unbanked using prepaid platforms and mobile telephones in the United States', Unpublished dissertation, University of Nevarra.
Reeves, M. \& Sabharwal, N., 2013, 'Microfinance and mobile banking for the bottom of the pyramid', Journal of Enterprising Communities: People and Places in the Global Economy 7(2), 155-166. https://doi.org/10.1108/17506201311325805

Saleh, I.M. \& Khine, M.S., 2011, Attitude research in science education, Library of congress, Springer, New York.

SASSA, 2017, You and your grants, viewed 09 February 2019 from http://www.sassa. gov.za/index.php/knowledge-centre/grant-booklets?start=6.

Shoprite, 2015, Money market, viewed 25 May 2015, from http://www.shoprite.co. za/pages/moneymarket.aspx.

Spasford, R. \& Jupp, V., 2006, Data collection and analysis, 2nd edn., Sage, London.

Standard Bank, 2014, Instant Money, viewed 28 February 2015, from http://www. standardbank.co.za/standardbank/personal/self-service-banking/help/instant-money.

Struwig, F.W. \& Stead, G.B., 2013, Planning, designing and reporting framework, 2nd edn., Pearson Education, Cape Town.

The World Bank, 2017, An overview of financial inclusion, viewed 01 February 2017, from http://www.worldbank..2org/en/topic/financialinclusion/overview.

Thomas, P.M., 2003, Blending qualitative and quantitative research methods in Thesis and Dissertations, Sage, Thousand Oaks, CA.

Venkatesh, V. \& Bala, H., 2008, 'Technology acceptance model and a research agenda on interventions', Decision Sciences 39(2), 273-315. https://doi. org/10.1111/j.1540-5915.2008.00192.x

Yeboah-Boateng, E.O. \& Amanor, P.M., 2014, 'Phishing, smishing and vishing: An assessment of threats against mobile devices', Journal of Emerging Trends in Computing and Information Sciences 5(4), 297-307.

Zikmund, W.G., Babin, J.B., Carr, J.C. \& Griffin, M., 2012, Business research methods, 9th edn., Cengage Learning: South-Western. 